\title{
FIXED AMMONIUM IN SOME FINNISH SOILS
}

\author{
Armi Kaila \\ University of Helsinki, Department of Agricultural Chemistry
}

Received November 15, 1965

Recently, the occurrence in soils of native fixed ammonium has been the object of several works in various parts of the world. In 1954 RoDRIGUES (12) reported that from 14 to 78 per cent of the total nitrogen content of the tropical soils examined existed as fixed ammonium, extractable by hydrofluoric acid and presumable present in association with certain clay minerals. Two years later, HANWAY and Scotr (7) stated that there was some naturally occurring fixed ammonium in the Iowa soils studied: in the samples from the B and C horizons as much as 25 per cent of the total nitrogen was in this form. BREMNER and HARAdA (3) concluded that some mineral soils contain a significant quantity of ammonium and organic matter intimately associated with clay minerals. They found that 4 to 8 per cent of the nitrogen in surface soils and 19 to 45 per cent of the nitrogen in subsoils examined was in the form of fixed ammonium. Stevenson and Dhariwal (17) suppose that a vast reservoir of nitrogen exists in the terrestrial areas of the world as ammonium held with the lattice structure of clay minerals. There is, however, also some evidence of the occurrence of ammonium- $\mathrm{N}$ in the coarser fractions of soil and even in the rocks. According to Schachtschabel (14), muscovite contained $52 \mathrm{mg}$, biotite $8 \mathrm{mg}$, and potassium feldspar $14 \mathrm{mg} \mathrm{NH}_{4}-\mathrm{N}$ per $100 \mathrm{~g}$ of the mineral. In the granites analysed by STEvenson (16), 24 to 56 per cent of total nitrogen was ammoniacal, in the shales the proportion ranged from 52 to 68 per cent.

The results reported on the content of indigenous fixed or nonexchangeable $\mathrm{NH}_{4}-\mathrm{N}$ in the soils of U.S.A. (e.g. 17, 18, 20, 22), Canada (8, 10), Germany $(13,14)$, and Nigeria (11) range from negligible quantities up to $850 \mathrm{ppm}$. Usually, the surface soils contain lower amounts of this kind of nitrogen than do the soils from deeper layers. In the surface soils, the content of fixed $\mathrm{NH}_{4}-\mathrm{N}$ corresponds, on the average, to less than 10 per cent of the Kjeldahl-N, in the subsoils this proportion is likely to be markedly higher, and in some soils it may even exceed 60 per cent. Thus, in many soils the fixed ammonium appears to represent a considerable part of the total nitrogen, and often it may be higher than the sum of exchangeable $\mathrm{NH}_{4}-\mathrm{N}$, $\mathrm{NO}_{2}-\mathrm{N}$ and $\mathrm{NO}_{3}-\mathrm{N}$. 
On the other hand, it has been claimed that the methods used for the determination of the indigenous fixed ammonium are likely to lead to erroneusly high results, because they may include nitrogen released from the organic compounds by the treatment. In the procedure adopted by Dhariwal and Stevenson (4) the soil sample is pretreated with $1 \mathrm{~N} \mathrm{KOH}$ at $120^{\circ} \mathrm{C}$ in order to remove labile organic nitrogen compounds before the fixed ammonium is released by the treatment with acid $\mathrm{HF}$ at room temperature. FRENEY (6), however, declares that the pretreatment may not affect organic matter in clay mineral lattices, and that the fixed ammonium is derived from organic compounds. Schachtschabel (14) also claims that it is not proved that all the disturbing organic nitrogen compounds will be removed. On the other hand, he doubts whether all the fixed ammonium will be released by $\mathrm{HF}$ at room temperature. He also thinks that the other largely used method, that of BREMnER (1), will not determine all the fixed ammonium. This procedure is based on the estimation of the difference in the amounts of ammonium released on treatment with $1 \mathrm{~N} \mathrm{HF}: 1 \mathrm{~N} \mathrm{HCl}$ at room temperature and that extracted with $1 \mathrm{~N} \mathrm{KCl}$.

In the method proposed by Schachtschabel $(13,14)$, the fixed ammonium is released by heating the sample in concentrated $\mathrm{H}_{2} \mathrm{SO}_{4}$ and $40 \% \mathrm{HF}$ after the destruction of the main part of the organic matter in the soil with $\mathrm{H}_{2} \mathrm{O}_{2}$ in the presence of $\mathrm{KCl}$. Since all organic matter is not oxidized by this pretreatment, an empirically estimated correction is used: $3 \mathrm{mg} \mathrm{N}$ per $100 \mathrm{mg}$ of $\mathrm{C}$ in the oxidized sample is subtracted from the amount of $\mathrm{NH}_{4}-\mathrm{N}$ found when the nitrogen liberated by the $\mathrm{H}_{2} \mathrm{SO}_{4}$ - $\mathrm{HF}$ treatment is distilled with $\mathrm{NaOH}$. The value of this procedure largely depends on the effectiveness of potassium to prevent the fixation of ammonium released from organic compounds by the oxidation with $\mathrm{H}_{2} \mathrm{O}_{2}$. The probable errors originating from the inaccuracy of the correction factor appear to be relatively low, as shown by Schachtschabel (14). He himself considers this method conventional and as such comparable to the procedures used for the determination of the exchangeable cations in the soil.

This method was chosen for the present work the aim of which was to get some idea of the occurrence of indigenous nonexchangeable ammonium in Finnish soils. Because of the predominance in their clay fraction of illite minerals supposed to be rich in fixed ammonium, they may contain significant amounts of this kind of nitrogen.

Material and methods

The material of the present work consists of 130 samples of mineral soils collected from various parts of Finland. The topsoil samples are from the surface layer down to about $20 \mathrm{~cm}$, and the subsoil samples repsesent deeper layers, mainly from the depths of 20 to $40 \mathrm{~cm}$ or 40 to $60 \mathrm{~cm}$, but some of them are even from the depth of more than $2 \mathrm{~m}$. Both cultivated and virgin lands were sampled.

The proportion of clay soils in the material is relatively high: 20 of the $\mathbf{4 4}$ topsoil samples and $\mathbf{6 4}$ of the 86 subsoil samples contain more than 30 per cent of the fraction less than $2 \mu$. The samples of the mon-clay soils" represent 21 silt soils, 16 loam soils, and 9 finesand soils.

The samples were air-dried and ground. Soil $\mathrm{pH}$ was measured in $0,01 \mathrm{M} \mathrm{CaCl}_{2}$ in the ratio of soil to solution of $1: 2.5$. Organic carbon was estimated by the method of WALKLEY (19), using the iodometric titration. The regular Kjeldahl-digestion with copper sulfate as the catalyst was used for the determination of soil nitrogen. 
The fixation of applied ammonium nitrogen in difficultly exchangeable forms was determined by the somewhat modified method of SснаснтsснавеL used in a previous work (9).

The procedure for the estimation of the indigenous fixed ammonium was the following (14):

$5 \mathrm{ml}$ of $10 \% \mathrm{KCl}$ solution and $25 \mathrm{ml}$ of $30 \% \mathrm{H}_{2} \mathrm{O}_{2}$ were added to $10 \mathrm{~g}$ of soil. The suspension was allowed to stand overnight and heated on water-bath for one hour. $25 \mathrm{ml}$ of $30 \% \mathrm{H}_{2} \mathrm{O}_{2}$ was added and the mixture was heated for two hours, then washed twice with $300 \mathrm{ml}$ of $0.05 \mathrm{~N} \mathrm{HCl}$, once with water, and at last with alcohol. The residue was dried at $50^{\circ} \mathrm{C}$ and its content of organic $\mathrm{C}$ was determined.

$2 \mathrm{~g}$ (clay soils) or $4 \mathrm{~g}$ (non-clay soils) of the residue was placed in a platinum crucible, $3 \mathrm{ml}$ of conc. $\mathrm{H}_{2} \mathrm{SO}_{4}$ added, and allowed to stand for one hour, then heated on a sand bath until $\mathrm{H}_{2} \mathrm{SO}_{4}$-fumes appear. $3 \mathrm{ml}$ of water is added after cooling, then $5 \mathrm{ml}$ of $40 \% \mathrm{HF}$, and after heating, $15 \mathrm{ml}$ of $40 \%$ $\mathrm{HF}$ in two portions. When the mixture has been evaporated to $\mathrm{H}_{2} \mathrm{SO}_{4}$-fumes, the residue is disintegrated in water. The suspension is transferred to distillation flask, $20 \mathrm{ml}$ of $50 \% \mathrm{NaOH}$ added, and the ammonia distilled by steam in the boric acid-indicator solution.

The amount of fixed $\mathrm{NH}_{4}-\mathrm{N}$ is obtained by subtracting from this result $3 \mathrm{mg}$ of $\mathrm{N}$ per 100 $\mathrm{mg}$ of organic $\mathrm{C}$ in the $\mathrm{H}_{2} \mathrm{O}_{2}$-treated sample.

Table 1. Soil samples.

\begin{tabular}{|c|c|c|c|c|c|c|}
\hline & \multirow{2}{*}{\multicolumn{2}{|c|}{ 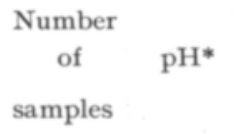 }} & \multicolumn{2}{|c|}{ Clay $\% *$} & \multirow{2}{*}{$\begin{array}{l}\text { Org. C* } \\
\%\end{array}$} & \multirow{2}{*}{$\begin{array}{c}\text { Kjeldahl-N* } \\
\mathrm{mg} / \mathrm{g}\end{array}$} \\
\hline & & & $<0.6 \mu$ & $0.6-2 \mu$ & & \\
\hline \multicolumn{7}{|l|}{ Topsoil samples } \\
\hline Non-clay soils & 24 & $5.1 \pm 0.2$ & $9 \pm 2$ & $11 \pm 2$ & $2.93 \pm 0.59$ & $2.18 \pm 0.42$ \\
\hline Clay soils & 20 & $5.1 \pm 0.3$ & $29 \pm 5$ & $18 \pm 2$ & $3.68 \pm 0.73$ & $2.97 \pm 0.44$ \\
\hline \multicolumn{7}{|l|}{ Subsoil samples } \\
\hline Non-clay soils & 22 & $5.4 \pm 0.3$ & $6 \pm 2$ & $14 \pm 2$ & $0.55 \pm 0.24$ & $0.44 \pm 0.15$ \\
\hline Clay loam & 12 & $4.7 \pm 0.6$ & $32 \pm 6$ & $13 \pm 1$ & $0.99 \pm 0.64$ & $1.08 \pm 0.55$ \\
\hline Silty clay & 24 & $5.5 \pm 0.3$ & $23 \pm 4$ & $21 \pm 3$ & $0.58 \pm 0.26$ & $0.69 \pm 0.31$ \\
\hline Heavy clay & 28 & $6.0 \pm 0.3$ & $61 \pm 5$ & $17 \pm 2$ & $0.43 \pm 0.13$ & $0.73 \pm 0.14$ \\
\hline
\end{tabular}

*Means with the confidence limits at the 95 per cent level.

\section{Results}

The material is characterized by the data recorded in Table 1 . Because of the small number of the finesand, loam and silt soils, they are treated as one group, the mon-clay soils». The topsoil group of clay soils includes 6 samples of clay loam, 10 of silty clay, and 4 of heavy clay.

The $\mathrm{pH}$-value of the samples ranged from $\mathrm{pH} 3.3$ to $\mathrm{pH} 7.5$. The clay content, the fraction less than $2 \mu$, varied between 0 and 96 per cent, and the fraction of the finer clay, less than $0,6 \mu$, between 0 and 86 per cent. The minimum content of organic $\mathrm{C}$ was 0.03 per cent, and the maximum 6.58 per cent. The corresponding limits of the content of Kjeldahl-N were 0.13 and $4.53 \mathrm{mg} / \mathrm{g}$, respectively. Thus, the samples represent a fairly heterogenous material.

The results of the estimation of the indigenous fixed ammonium in these samples are reported in Table 2 as the mean values and the corresponding ranges for the 
Table 2. Fixed $\mathrm{NH}_{4}-\mathrm{N}$.

\begin{tabular}{|c|c|c|c|c|}
\hline & \multicolumn{4}{|c|}{ Fixed $\mathrm{NH}_{4}-\mathrm{N}$} \\
\hline & \multicolumn{2}{|c|}{ ppm } & \multicolumn{2}{|c|}{ per cent of Kjeldahl-N } \\
\hline & mean* & range & mean* & range \\
\hline \multicolumn{5}{|l|}{ Topsoil samples } \\
\hline Non-clay soils & $70 \pm 25$ & $0-188$ & $4 \pm 2$ & $0-13$ \\
\hline Clay soils & $220 \pm 54$ & $36-446$ & $\mathbf{9} \pm \mathbf{3}$ & $1-19$ \\
\hline \multicolumn{5}{|l|}{ Subsoil samples } \\
\hline Non-clay soils & $115 \pm 15$ & $52-188$ & $41 \pm 11$ & $5-92$ \\
\hline Clay loam & $247 \pm 43$ & $156-358$ & $62 \pm 8$ & $8-92$ \\
\hline Silty clay & $234 \pm 45$ & $49-455$ & $55 \pm 11$ & $9-93$ \\
\hline Heavy clay & $403 \pm 36$ & $261-623$ & $62 \pm 8$ & $16-92$ \\
\hline
\end{tabular}

*Means with the confidence limits at the 95 per cent level.

various soil groups. No fixed $\mathrm{NH}_{4}-\mathrm{N}$ could be found in one finesand soil, one loam soil and three samples of silt soils of the top layer. More than $400 \mathrm{ppm}$ was found in 15 samples of heavy clay and 2 samples of silty clay, all of them from the deeper layers. The subsoil samples with an average content of $260 \pm 30 \mathrm{ppm}$ are richer than the topsoil samples with the average of $140 \pm 40 \mathrm{ppm}$. This is particularly due to the high content of fixed ammonium in the heavy clay samples from the deeper layers. No significant difference exists between the mean contents of the topsoil and subsoil groups of clay loam or silty clay, and in the finesand, loam and silt soil groups the range of the topsoil samples overlaps that of the subsoil samples. The mean content of fixed ammonium in the clay soils, $290 \pm 30 \mathrm{ppm}$, is far higher than that in the soils of the coarser texture, $90 \pm 30 \mathrm{ppm}$. No difference could be detected between the mean contents in the finesand, loam and silt soils.

In order to give some idea about the proportion of this native fixed ammonium in the soil, the results are also reported as a percentage of the Kjeldahl-N. This does not mean that the Kjeldahl-N would in all soils include the total amount of the fixed ammonium. STEvart and Porter (15) claim that some soils contain a form of indigenous fixed ammonium which is not removed by Kjeldahl procedures. Moore (10) also found small quantities of nitrogen, from 18 to $59 \mathrm{ppm}$, when the residues from the Kjeldahl-digestion were treated with $\mathrm{HF}$ : $\mathrm{HCl}$. On the other hand, BREMNER (2) states that $\mathrm{NH}_{4}-\mathrm{N}$ fixed by clay minerals is determined by the Kjeldahl method. In the present study, no nitrogen was released from the residues of the Kjeldahl-digestion of twenty samples when these were treated with $\mathrm{H}_{2} \mathrm{SO}_{4}: \mathrm{HF}$ according to the method used for the estimation of fixed ammonium. This, however, does not exclude the possibility that some other samples may contain ammonium which is more strongly fixed.

In the topsoil samples the amount of fixed $\mathrm{NH}_{4}-\mathrm{N}$ is, of course, small as compared with the content of Kjeldahl-N, but in the samples of the deeper layers it 
equals, on the average, about one half of the Kjeldahl-N, in the extreme cases even more than 90 per cent of it. These highest values were mainly found for soils with a very low content of organic carbon.

In the topsoil samples the content of fixed ammonium corresponds, on the average, to $6 \pm 2$ per cent of the Kjeldahl-N. This is in accordance with the results reported in other papers. The corresponding mean value for the subsoil samples, $52 \pm 5 \%$, is, however, higher than those found in the literature.

As far as the nonexchangeable ammonium in soil is in the lattices of clay minerals, its quantity is likely to depend on the clay content of the soil, provided that the mineral composition of the clay material is fairly homogenous. A close correlation between the clay content of the soil and the amount of fixed ammonium has been reported by் Schachtschabel (14) who found a linear correlation coefficient $\mathrm{r}=0.91^{* * *}$ for the marsh soils and $\mathrm{r}=0.92^{* * *}$ for the loess soils studied. YounG and Cattani (22), on the other hand, did not find any correlation between these variables. Relationship in the present material is reported in Table 3.

The fixed ammonium in the finesand, loam and silt soils seems to have no connection with the clay content of these soils. In the clay soils, the clay fraction appears to be of importance, but only the finer clay material has to be taken into account. In all the samples about 70 per cent of the variation in the content of fixed $\mathrm{NH}_{4}-\mathrm{N}$ may be explained by the variation in the content of finer clay in these soils.

Table 3. Correlation coefficients for the relation between fixed $\mathrm{NH}_{4}-\mathrm{N}$ content and the clay fractions.

\begin{tabular}{llcc}
\hline & & & \\
& $\begin{array}{c}\text { Clay } \\
<2 \mu\end{array}$ & $\begin{array}{c}\text { Coarser clay } \\
0.6-2 \mu\end{array}$ & $\begin{array}{c}\text { Finer clay } \\
\mu\end{array}$ \\
& & & 0.6 \\
Non-clay soils (46 samples) & 0.20 & 0.14 & $0.74^{* * *}$ \\
Clay soils (84 samples) & $0.76^{* * *}$ & -0.15 & $0.84^{* * *}$ \\
All samples (130) & $0.85^{* * *}$ & $0.23^{* *}$ & \\
\hline
\end{tabular}

Table 4. Native fixed ammonium and fixation of applied ammonium.

\begin{tabular}{lcc}
\hline & $\begin{array}{c}\text { Fixed } \mathrm{NH}_{4}-\mathrm{N} \text { m.e./100 } \mathrm{g} \text { soil* } \\
\text { native }\end{array}$ & \\
\hline Topsoil samples & & \\
Non-clay soils & $0.5 \pm 0.2$ & $0.8 \pm 0.3$ \\
Clay soils & $1.6 \pm 0.4$ & $1.2 \pm 0.4$ \\
Subsoil samples & & \\
Non-clay soils & $0.8 \pm 0.1$ & $2.3 \pm 1.0$ \\
Clay loam & $1.8 \pm 0.3$ & $2.5 \pm 1.3$ \\
Silty clay & $1.6 \pm 0.4$ & $5.8 \pm 1.5$ \\
Heavy clay & $2.9 \pm 0.3$ & $6.0 \pm 1.1$ \\
\hline
\end{tabular}

*Means with the confidence limits at the 95 per cent level. 
The capacity of these samples to fix applied ammonium nitrogen was also determined. When 1000 me of $\mathrm{NH}_{4}-\mathrm{N}$ per $100 \mathrm{~g}$ of soil was allowed to react with the samples for 24 hours at room temperature and without drying, the result reported in Table 4 were obtained. Under these conditions, the average amounts of the applied $\mathrm{NH}_{4}-\mathrm{N}$ fixed as nonchangeable forms in the topsoils are almost equal to those of the indigenous $\mathrm{NH}_{4}-\mathrm{N}$. In the subsoils, however, the former appears to be markedly higher than the latter, except in the clay loam soils. The relationship between these two variables is not close: the total linear correlation coefficients are $r=0.36^{*}$ in the topsoil, $\mathrm{r}=0.34 * *$ in the subsoils, and $\mathrm{r}=0.46 * * *$ in the whole material.

Actually, the term "ammonium fixing capacity" includes both the indigenous nonexchangeable forms of ammonium and those retained from the application of ammonium salts. As far as the data reported in Table 4 represent these two categories, the average fixing capacity in the heavy clay samples of the deeper layers would be as high as about $9 \mathrm{me} / 100 \mathrm{~g}$ soil and more than $7 \mathrm{me} / 100 \mathrm{~g}$ in the silty clay samples. In the topsoils, about one half of the capacity is saturated by the native fixed ammonium, this part being higher in the clay soils than in the soils of a coarser texture. The rate of saturation appears to be lower in the subsoils, particularly in the samples of silty clay.

Attention has been paid to the effect of the occurrence of fixed $\mathrm{NH}_{4}-\mathrm{N}$ in the soil on the ratio of $\mathrm{C} / \mathrm{N}$ (e.g. 10, 18, 21). Usually, this ratio is computed on the basis of the contents of organic carbon and Kjeldahl-nitrogen in the soil. If a smaller or larger part of the fixed $\mathrm{NH}_{4}-\mathrm{N}$ will be included in the Kjeldahl-N values, this ratio does not characterize the soil organic matter. In the present material, the ratio of organic $\mathrm{C}$ to Kjeldahl-N was in many samples very low pointing to this possibility. These figures are collected in Table 5 which also contains the ratios of the organic $\mathrm{C}$ content to the difference between the contents of Kjeldahl-N and fixed $\mathrm{NH}_{4}-\mathrm{N}_{\text {. }}$

Table 5. Ratio of organic $C$ to $N$.

\begin{tabular}{|c|c|c|c|c|}
\hline & \multicolumn{2}{|c|}{$\mathrm{C} / \mathrm{Kj}$ jeldahl-N } & \multirow{2}{*}{$\begin{array}{c}\mathrm{C} /(\mathrm{K} \text { jeldahl-N } \\
\text { mean* }\end{array}$} & \multirow{2}{*}{$\begin{array}{l}\left.\text { fixed } \mathrm{NH}_{4}-\mathrm{N}\right) \\
\text { range }\end{array}$} \\
\hline & mean* & range & & \\
\hline \multicolumn{5}{|l|}{ Topsoil samples } \\
\hline Non-clay soils & $14 \pm 2$ & $9-28$ & $14 \pm 2$ & $9-29$ \\
\hline Clay soils & $12 \pm 1$ & $8-17$ & $14 \pm 1$ & $9-17$ \\
\hline \multicolumn{5}{|l|}{ Subsoil samples } \\
\hline Non-clay soils & $11 \pm 2$ & $3-16$ & $18 \pm 2$ & $15-28$ \\
\hline Clay loam & $7 \pm 2$ & $4-11$ & $14 \pm 3$ & $10-30$ \\
\hline Silty clay & $9 \pm 1$ & $4-14$ & $23 \pm 5$ & $8-38$ \\
\hline Heavy clay & $5 \pm 1$ & $1-9$ & $18 \pm 6$ & $9-30$ \\
\hline
\end{tabular}

*Means with the confidence limits at the 95 per cent level.

In the topsoil samples the subtracting of the fixed $\mathrm{NH}_{4}-\mathrm{N}$ from the Kjeldahl- $\mathrm{N}$ does not change the mean $\mathrm{C} / \mathrm{N}$-ratio of the non-clay soils, and tends to increase it only slightly in the clay soils. In the subsoil samples, on the other hand, the effect 
is marked, particularly in the clay soils. It is possible that while the ratio of organic $\mathrm{C}$ to the Kjeldahl-N gives a too low estimate of the radio of these elements in the soil organic matter, the ratio obtained when the total amount of the fixed $\mathrm{NH}_{4}-\mathrm{N}$ is subtracted from the Kjeldahl-N may be too high, since all of this kind of inorganic nitrogen was not determined by the Kjeldahl-digestion.

\section{Discussion}

On the basis of these results obtained by the method of Schachtschabel, the content of nonexchangeable ammonium nitrogen in Finnish soils appears to be considerable. Ranging from 0 to $620 \mathrm{ppm}$, with the total average of $220 \mathrm{ppm} \pm 30$ it is of the same order as the fixed $\mathrm{NH}_{4}-\mathrm{N}$ content found by ScHAchtschabel (14) in the German loess and marsh soils, but does not reach their maximum, $850 \mathrm{ppm}$. If the heavy clay samples of the present material with the average content of about $400 \mathrm{ppm}$ were excluded, these results were also in accordance with the data obtained by the methods of Dhariwal and Stevenson and of Bremner in other countries: these seem to vary from 17 to $370 \mathrm{ppm}$.

In the clay soils studied about 55 per cent of the variation in the content of nonexchangeable $\mathrm{NH}_{4}-\mathrm{N}$ may be explained by the variation in the content of the clay less than $0.6 \mu$, while the coarser clay fraction seems to play no role. In the samples of finesand, loam and silt soils, no correlation could be detected between their clay content and the fixed $\mathrm{NH}_{4}-\mathrm{N}$. This may be taken to indicate that a large part of the fixed ammonium is in the coarser fractions. According to Hinman (8), from 20 to 46 per cent of the fixed $\mathrm{NH}_{4}-\mathrm{N}$ in the profiles studied occurred in the silt fraction. He also supposes that appreciable amounts of fixed $\mathrm{NH}_{4}$ may have been held on the very fine sand of some soils. Schachtschabel (14) found 18 and 28 per cent of the fixed $\mathrm{NH}_{4}-\mathrm{N}$ of the marsh and loess profiles in the material larger than $20 \mu$.

It is likely that the forms of the nonexchangeable ammonium varies in regard to the kind and the strength of the fixation. There may be ammonium ions which are relatively lately retained by clay minerals, and there may be ammonium nitrogen which has taken part in the geochemical processes of the formation of the minerals. It is not excluded that a part of the non-exchangeable $\mathrm{NH}_{4}-\mathrm{N}$ were associated with organic matter, as pointed out already by RoDRIGUES (12) and recently by Moore (10). In this connection the fact may be noteworthy that according to Evans (5) biogenic amino acids can survive in rocks and minerals for seemingly indefinite periods: e.g. alanine has been identified in pre-Cambrian rocks, about 1000 million years old.

The nonexchangeable forms of potassium may be of importance in the potassium nutrition of crops. Nothing definite is known about the value of the nonexchangeable ammonium nitrogen. Moore and Ayeke (11) suppose that, in the tropical areas at least, release of fixed $\mathrm{NH}_{4}$ in the subsoil may make a significant contribution to the biological nitrogen cycle. On the other hand, Hinman (8) found that in the Canadian soils studied cultivation had little or no effect on the amount of fixed ammonium in the surface soils, although the average total nitrogen content was 
reduced by one third of that in the virgin soils. As far as the fixation of ammonium nitrogen released from the organic matter or applied in fertilizers would significantly decrease the plant-available nitrogen, the relatively high saturation of the wfixing capacity" by indigenous $\mathrm{NH}_{4}-\mathrm{N}$ could be of importance. This, however, is not likely to be the case in most of our surface soils. More information is needed on the forms of fixed ammonium in soils before it is possible to estimate whether it will be of any value as a source of nitrogen for plants.

The occurrence of a relatively large part of the soil nitrogen as nonexchangeable ammonium hampers the determination of both the total nitrogen and the organic nitrogen, particularly in samples from deeper layers. The fact that the amount of nonexchangeable $\mathrm{NH}_{4}-\mathrm{N}$ corresponded to a very high percentage of the Kjeldahl-N in some of the samples studied, may be taken to indicate that the Kjeldahl-digestion did not release all the fixed ammonium. On the other hand, the extremely low ratio of organic C to Kjeldahl-N in several samples of the deeper layers shows that a part of this nitrogen was not in organic compounds. There is, of course, also the possibility that all the organic carbon in the clay lattice was not determined by the method used.

At last, the fact must be remembered that we do not know with certainty whether all the ammonium released by $\mathrm{HF}$ actually is indigenous inorganic nitrogen fixed in nonexchangeable forms. FRENEY (6) suggests that $\mathrm{NH}_{4}$-fixation is largely caused in the laboratory by using extractants containing potassium which trap exchangeable ammonium or by applying reagents which decompose organic nitrogen compounds.

\section{$S u m m$ ary}

The nonexchangeable or fixed $\mathrm{NH}_{4}-\mathrm{N}$ was determined by the method of Schachtschabel in 130 samples of Finnish mineral soils. In this relatively heterogeneous material consisting of 44 samples from the surface layer down to 20 $\mathrm{cm}$ and 86 samples from the deeper layers, the $\mathrm{pH}$ values ranged from 3.3 to 7.5 , the contents of clay from 0 to 96 per cent, organic $\mathrm{C}$ from 0.03 to 6.6 per cent, and Kjeldahl-N from 0.13 to $4.53 \mathrm{mg} / \mathrm{g}$.

In the 46 finesand, loam and silt soil samples, the content of nonexchangeable $\mathrm{NH}_{4}-\mathrm{N}$ was, on the average, $90 \pm 30 \mathrm{ppm}$ ranging from 0 to $190 \mathrm{ppm}$. In the 84 clay soil samples it ranged from 40 to $620 \mathrm{ppm}$, with an average of $290 \pm 30 \mathrm{ppm}$. The heavy clay soils of the deeper layers were particularly rich in fixed $\mathrm{NH}_{4}-\mathrm{N}$ containing it averagely $400 \pm 40 \mathrm{ppm}$. Because of these soils the mean value in the samples of the deeper layers was as high as $260 \pm 30 \mathrm{ppm}$ and thus significantly higher than the corresponding figure in the surface soils, $140 \pm 40 \mathrm{ppm}$.

In the clay soils the amount of nonexchangeable ammonium was correlated with the clay fraction less than $0.6 \mu\left(\mathrm{r}=0.74^{* * *}\right)$, but not at all with the coarser clay. In the finesand, loam, and silt soils no correlation between the contents of fixed ammonium and clay was detected.

No close relationship existed between the indigenous fixed ammonium and the capacity of the soil to fix applied ammonium. If the sum of these quantities would 
represent the total ammonium fixing capacity of the soil, about one half of this capacity would be saturated by the native fixed ammonium in the topsoil. In the subsoils the rate of saturation would be much lower.

In the topsoil samples the amount of nonexchangeable $\mathrm{NH}_{4}-\mathrm{N}$ corresponded in the non-clay soils to $4 \pm 2$ per cent and in the clay soils to $9 \pm 3$ per cent of the Kjeldahl-N. In the subsoil samples the corresponding average percentage was $52 \pm 5$.

The rather low ratios of organic $\mathrm{C}$ to Kjeldahl-N in the clay soils of the deeper layers may be taken to indicate that a part of the Kjeldahl-N was not in organic compounds. The $\mathrm{C} / \mathrm{N}$-ratios obtained when the amount of nonexchangeable $\mathrm{NH}_{4}-\mathrm{N}$ is subtracted from the Kjeldahl-N may be too high to characterize the soil organic matter, since it is likely that all the fixed $\mathrm{NH}_{4}-\mathrm{N}$ was not determined by the Kjeldahl-procedure.

\section{REFERENCES}

(1) Bremner, J. 1959. Determination of fixed ammonium in soil. J. Agric. Sci. 52: 147-160.

(2) -1960 . Determination of nitrogen in soil by the Kjeldahl method. Ibid. 55: $11-33$.

(3) - - \& HARADA, T. 1959. Release of ammonium and organic matter from soil by hydrofluoric acid and effect of hydrofluoric acid treatment on extraction of soil organic matter by neutral and alkaline reagents. Ibid. 52: 137-146.

(4) Dhariwal, A. P. S. \& Stevenson, F. J. 1958. Determination of fixed ammonium in soils. Soil Sci. 86: $343-349$.

(5) Evans, W. D. 1965. Facets of organic geochemistry. In Experimental Pedology: p. 14-27. London - 1965.

(6) Freney, J. R. 1964. An evaluation of naturally occurring fixed ammonium in soils. J. Agric. Sci. $63: 297-303$.

(7) Hanway, J. J. \& Scott, A. D. 1956. Ammonium fixation and release in certain Iowa soils. Soil Sci $82: 379-386$.

(8) Hinman, W. C. 1964. Fixed ammonium in some Saskatchewan soils. Can. J. Soil Sci. 44: $151-157$.

(9) KaIlA, A. 1962. Fixation of ammonium in Finnish soils. J. Sci. Agric. Soc. Finland 34: 107-114.

(10) Moore, A. W. 1965. Fixed ammonium in some Alberta soils. Can. J. Soil Sci. 45: 112-115.

(11) - - \& AYEKE, C. A. 1965. HF-extractable ammonium nitrogen in four Nigerian soils. Soil Sci. 99: $335-338$.

(12) Rodrigues, G. 1954. Fixed ammonia in tropical soils. J. Soil Sci. 5: 264-274.

(13) Sснаснтschabel. P. 1960. Fixierter Ammoniumstickstoff in Löss- und Marschböden. 7 th Int. Congr. Soil Sci. II: $22-27$.

(14) - 1961. Bestimmung des fixierten Ammoniums in Boden. Zeitschr. f. Pflanzenern. Düng. Bodenk. 93: 125-136.

(15) Stewart, B. A. \& Porter, L. K. 1963. Inability of the Kjeldahl method to fully measure indigenous fixed ammonium in some soils. Soil Sci. Soc. Amer. Proc. 27: 41-43.

(16) Stevenson, F. J. 1959. Fixed ammonium in rocks. Science 129: 221-222.

(17) - - \& Dhariwal, A. P. S. 1959. Distribution of fixed ammonium in soils. Soil Sci. Soc. Amer. Proc. 23: $121-125$.

(18) - - , - \& C,-- HOUdRI, M. B. 1958. Further evidence for naturally occurring fixed ammonium in soils. Soil Sci. 85: $42-46$.

(19) WALKLEY, A. 1935. An examination of methods for determining organic carbon and nitrogen in soils. J. Agric. Sci. 25: 598-600.

(20) Walsh, L. M. \& MUrdock, J. T. 1960. Native fixed ammonium and fixation of applied ammonium in several Wisconsin soils. Soil Sci. 89: 189-193. 
(21) Young, J. L. 1962. Inorganic soil nitrogen and carbon: nitrogen relations of some Pacific Northwest soils. Ibid. 93: $397-404$.

(22) - - \& CAtrani, R. A. 1962. Mineral fixation of anhydrous $\mathrm{NH}_{3}$ by airdry soils. Soil Sci. Soc. Amer. Proc. 26: 147-152.

SELOSTUS:

VAIHTUMATTOMASTA AMMONIUMISTA MAISSAMME

Armi Kaila

Yliopiston maanviljelyskemian laitos, Viikki

Käyttämällä SснаснтsснAвELin menetelmää määritettiin vaihtumaton ammoniumtyppi 130 kivennäismaanäytteestä, joista 44 oli pintakerroksesta ja 86 syvemmistä kerroksista.

Hieta-, hiue- ja hiesumaitten vaihtumattoman $\mathrm{NH}_{4}-\mathrm{N}: \mathrm{n}$ mäărä vaihteli $0-190 \mathrm{mg} / \mathrm{kg}$, keskiarvo oli $90 \pm 30 \mathrm{mg} / \mathrm{kg}$. Savimaissa vaihtelualue oli $40-620 \mathrm{mg} / \mathrm{kg}$ ja keskimäärä $290 \pm 30 \mathrm{mg} / \mathrm{kg}$. Syvempien kerrosten jäykän saven näytteet sisälsivät vaihtumatonta ammoniumtyppeä keskimäärin $400+40$ $\mathrm{mg} / \mathrm{kg}$ ja ne kohottivat syvempien kerrosten keskipitoisuuden $260 \pm 30 \mathrm{mg} / \mathrm{kg}$ : ksi, joka on merkittävästi suurempi kuin pintakerrosten näytteiden $140+40 \mathrm{mg} / \mathrm{kg}$.

Savimaissa vaihtumattoman ammoniumin määrä oli vuorosuhteessa hienon saveksen, alle $0,6 \mu$. kanssa $\left(\mathrm{r}=0,74^{* * *}\right)$, mutta ei karkeamman saveksen. Karkeammissa maissa ei voitu todeta korrelaatiota vaihtumattoman ammoniumin ja saveksen välillä.

Maahan lisätyn ammoniumin pidätyskyvyn ja maassa olevan vaihtumattoman ammoniumin välillä oli vain heikko riippuvuus. Mikäli näiden arvojen summan voidaan katsoa edustavan maan ammoniumin pidätyksen kokonaiskapasiteettia, näyttää noin puolet siitä olevan maan pintakerroksessa vaihtumattoman ammoniumin kyllästämänä. Syvemmissä kerroksissa kyllästysaste on paljon matalampi.

Vaihtumattoman ammoniumtypen määrä vastasi pintakerroksissa keskimäärin alle $10 \%$ Kjeldahl-typestä. Syvemmissä kerroksissa vastaava prosentti oli noin 50. Varsinkin syvempien kerrosten savinäytteissä C/N laskettuna orgaanisen hiilen ja Kjeldahl-typen suhteena oli verraten matala, keskimäärin noin 7 minimin ollessa vain 1, mikä viitannee siihen, että näissä näytteissä melkoinen osa Kjeldahl-typestä oli epäorgaanista. Koska tavallinen Kjeldahl-poltto ei ilmeisesti kaikissa maissa vapauta vaihtumatonta ammoniumia kokonaisuudessaan, antanee Kjeldahl-typen ja vaihtumattoman $\mathrm{NH}_{4}-\mathrm{N}_{\mathbf{n}}$ erotus lian pienen orgaanisen typen arvon. 